Review

\title{
The Impact on Dietary Outcomes of Celebrities and Influencers in Marketing Unhealthy Foods to Children: A Systematic Review and Meta-Analysis
}

\author{
Jessica Packer ${ }^{1, *}$, Simon J. Russell ${ }^{1}$, Gabriela Siovolgyi ${ }^{1}$, Katie McLaren ${ }^{1} \mathbb{D}$, Claire Stansfield $^{2}$, \\ Russell M. Viner ${ }^{1,+}$ and Helen Croker ${ }^{1,+}$
}

check for

updates

Citation: Packer, J.; Russell, S.J.;

Siovolgyi, G.; McLaren, K.; Stansfield,

C.; Viner, R.M.; Croker, H. The

Impact on Dietary Outcomes of

Celebrities and Influencers in

Marketing Unhealthy Foods to

Children: A Systematic Review and

Meta-Analysis. Nutrients 2022, 14,

434. https://doi.org/10.3390/

nu14030434

Academic Editor: Zhiyong Zou

Received: 22 December 2021

Accepted: 17 January 2022

Published: 19 January 2022

Publisher's Note: MDPI stays neutral with regard to jurisdictional claims in published maps and institutional affiliations.

Copyright: (C) 2022 by the authors. Licensee MDPI, Basel, Switzerland. This article is an open access article distributed under the terms and conditions of the Creative Commons Attribution (CC BY) license (https:// creativecommons.org/licenses/by/ $4.0 /)$.
1 Population, Policy and Practice Research and Teaching Department, UCL Great Ormond Street Institute of Child Health, University College London, London WC1N 1EH, UK; s.russell@ucl.ac.uk (S.J.R.); gabrielansiovolgyi@gmail.com (G.S.); katie.mclaren@hotmail.co.uk (K.M.); r.viner@ucl.ac.uk (R.M.V.); h.croker@wcrf.org (H.C.)

2 EPPI-Centre, UCL Social Research Institute, University College London, London WC1H 0NR, UK; c.stansfield@ucl.ac.uk

* Correspondence: jessica.packer@ucl.ac.uk

+ These authors contributed equally to this work.

\begin{abstract}
Celebrities, including influencers, are commonly used to market products that are high in fat, sugar, and salt (HFSS) to children but the impact on dietary outcomes has been unclear. The primary aim of this study was to systematically review the literature and quantify the impact of celebrities in HFSS marketing on children's dietary outcomes. We searched eight databases and included studies from all countries and languages published from 2009 until August 2021. Participants were defined as under 16 years, exposure was marketing for HFSS products with a celebrity, and the outcomes were dietary preference, purchasing behaviors, and consumption of HFSS products. We were able to conduct a meta-analysis for consumption outcomes. Seven articles met the inclusion criteria, of which three were included in the meta-analysis. Under experimental conditions, the use of celebrities in HFSS marketing compared to non-food marketing was found to significantly increase consumption of the marketed HFSS product by $56.4 \mathrm{kcals}(p=0.021)$. There was limited evidence on the impact on preference or purchase intentions and on the comparisons between use and non-use of celebrities and influencers.
\end{abstract}

Keywords: child and adolescent health; food marketing; obesity; policy research

\section{Introduction}

Increased exposure to high in fat, sugar, and salt (HFSS) marketing is occurring simultaneously with the global childhood obesity epidemic [1]. The marketing of unhealthy foods is ubiquitous and is particularly impactful for children and young people (the term 'marketing' includes both advertising and packaging) [2]. Children are exposed to marketing throughout the food environment, including via television and other broadcast media, in shops and supermarkets, on the street, and, increasingly, online [3]. The majority of food marketing is for HFSS products, some of which is directly targeted at children $[4,5]$. Evidence suggests that children from ethnic minority and lower socioeconomic groups are disproportionately exposed to, and influenced by, food marketing [6]. Children with higher body weight have also been found to be disproportionately affected by screen advertising for HFSS products [7].

The need for enhanced regulations of commercial marketing is a priority on the global health and policy agenda, as highlighted in a recent WHO-UNICEF-Lancet child health Commission [8]. This follows on from the 2010 WHO recommendations, for policies to limit the effectiveness of HFSS food marketing to children by limiting its exposure and 
power (the creative content, design, and execution of the marketing message/impacted by techniques used) [9]. In the accompanying WHO implementation guidance, restricting the use of celebrities in HFSS product marketing was used as a specific example of how to reduce the power of marketing [10]. Celebrity endorsements, across a broad array of categories, including HFSS food products, have been shown to increase sales, bring about more positive attitudes to brand and product, and increase purchase intentions [11-14].

Celebrity endorsements are thought to work through the process of evaluative conditioning, where liking of a stimulus is the result of its pairing with other positive stimuli [15]. This process is mediated by the parasocial relationships children can form with celebrities (one-sided relationships between media users and celebrities), especially through social media interaction [16]. A cross-disciplinary review examining how celebrities influence patients' health-related behaviors found that they can help distinguish products and elicit herd behavior (economics); transfer positive characteristics to the endorsed products (marketing); activate brain regions associated with trust, creating positive associations and encoding memories (neuroscience); and cause positive reactions (psychology) [17]. This results in the possibility of celebrities having a substantial influence on people's health-related behaviors.

Current restrictions on the use of celebrities in marketing of HFSS products to children have been identified as an area of concern [18-20]. Whilst the UK, Ireland, Chile, Australia, Netherlands, Portugal, Spain, and Brazil restrict the use of celebrities in HFSS advertising to children, loopholes exist in the interpretation of defining celebrities and audience thresholds, and the implementation of regulations [19,21-24]. In the UK, for example, the use of celebrities 'popular with children' is restricted in broadcast and non-broadcast HFSS advertisements targeting pre- and primary school children (under 12 years) but no definition of what constitutes a celebrity 'popular with children' is provided $[25,26]$. Additionally, the regulation of restrictions varies between self-regulated or statutory legislation. Evidence has shown that self-regulation is broadly ineffective at limiting HFSS marketing to children [19,27-29]. An example of voluntary and self-regulated restrictions is the Spanish Publicidad, Actividad, Obesidad, Salud (PAOS) Code for food and drinks marketing to children, which prevents the participation, appearance, and exploitation of well-known and famous persons [30]. The scope of restrictions is mainly focused on broadcast marketing, with packaging, sponsorship, cinema, and in-store promotions commonly neglected $[18,19]$. Restrictions frequently apply only to pre-digital media and need to be updated to react to changes in marketing and media consumption, with digital marketing now accounting for the majority of UK advertising spend [18,31]. Children as young as 3-4 years old are increasingly switching their preference and usage from TV to online (e.g., YouTube), and YouTube is growing as the preferred platform [3]. This has led to a new type of celebrity, the 'influencer' (or YouTuber), defined as gaining fame by successfully branding themselves as experts on social media platforms [32], which has been identified as a new marketing source targeting children [33]. Experiments have shown that influencer marketing leads to greater purchase intentions due to participants identifying, relating to and trusting influencers more than other celebrities [32]. Evidence suggests that the integration of 'real-life' scenarios into social media marketing (use of advertised product in their daily lives) leads to greater positive brand effects (brand attitude, purchase intention, willingness to pay for a product, and feeling connected to the brand) compared to traditional commercial celebrity-endorsed advertising [34]. Sports celebrities are also of interest in our review, with research showing that their association with high-sugar products can foster beliefs in children that they are healthy and improve sports performance [35].

Content analyses show that food marketing featuring celebrities is particularly prominent for HFSS products [36-39]. This was consistent across television advertisements in the UK [36] and musician [37], athlete [38], and YouTube influencer endorsements in the US [39]. Celebrities are also used on HFSS product packaging [40]. Analysis of social media advertising exposure in children aged 7-16 years found that during 10 min of social media use, $72 \%$ were exposed to food advertising, primarily for HFSS products, of which $17 \%$ 
was embedded in celebrity generated content [41]. Embedded content is not explicitly advertising, adding to the difficulty children already face in recognizing online advertising and impacting their ability to understand the intent of advertising [42,43]. A longitudinal study, looking at the association between self-reported vlog (i.e., video weblogs) viewing and consumption of HFSS beverages or snacks at three time points, found a significant association between exposure and consumption of HFSS beverages 24 months later [44].

Despite the widespread use of celebrities in the marketing of HFSS products and given the evidence of their impact on dietary outcomes, there have been no systematic reviews to date examining their impact on preference, purchasing, and consumption outcomes in children. Reviews have reported that celebrities are a popular marketing tactic for promoting HFSS foods to children but impacts on outcomes have rarely been assessed $[45,46]$. One review examined the impact of food marketing tactics on children's attitudes, preferences, and consumption and included the use of endorsers but found only limited evidence relating to advertising with celebrities [47]. Another review found evidence that celebrity endorsements positively impact brand attitudes and purchase intentions but included only one study in adolescents [11]. Due to these gaps in the literature, we undertook a review to better understand how celebrities used in HFSS food marketing (advertising and packaging) impact on children's food preferences, purchasing behaviors, and consumption. Our secondary aims were to assess the differential impact of the type of celebrity (sports, YouTubers/influencers, or other), child characteristics (age and socio-economic status), format of advertisement (content within advertisements versus on packaging), and length of any effects (short- or long-term).

\section{Materials and Methods}

\subsection{Protocol and Registration}

The current systematic review and meta-analysis was conducted and reported in accordance with the PRISMA statement checklist and was registered with PROSPERO (CRD42019155037) [48].

\subsection{Eligibility Criteria, Information Resources, and Search Strategy}

To be eligible for inclusion, studies needed to be quantitative, experimental (randomized or non-randomized) with an advertising exposure featuring a celebrity and a comparison group (non-food advertisement, no exposure, healthy food advertisement), or "real-world" (longitudinal, interrupted time series, controlled before and after). Studies from 2009, in any country or language, were included, as well as both between-subject and within-subject designs. Studies before 2009 were excluded as they were likely to be of limited relevance due to rapid advancement of technology and celebrity/influencer culture. Participant criteria were children aged between 0 and 15 years, in line with UK advertising regulations. Any marketing modality (TV, online, internet/advergames, poster, packaging, digital advertising) with a celebrity/influencer was eligible. Outcomes were all related to the advertised HFSS food product and included consumption (measured dietary intake, ad libitum consumption), preferences (self-reported, like/dislike ratings), and purchasing/request (quantity of product purchased, pester intention).

Searches of the following electronic databases were conducted on 22 October 2019 and updated on 16 August 2021: Ovid MEDLINE, Cochrane Library, Scopus, PsycINFO, ProQuest (Central)—ASSIA, Web of Science-Social Science Citation Index and Emerging Sources Citation Index and Social Policy and Practice (see Supplementary Table S1 for full search details and Supplementary Table S2 for search strings). K.M., G.S., and J.P. conducted the searches, imported records into EndNoteX9 and EPPI-Reviewer 4 and removed duplicates. EPPI-Reviewer 4 was used for screening and for search management [49].

\subsection{Study Selection}

Exclusion criteria were date (published pre-2009), participant age group (over 16 years), study design (qualitative, content analyses, cross-sectional), publication type (reviews, 
dissertations), intervention (no HFSS marketing exposure with a celebrity), and outcome measure (no measure of food intake, consumption, choice, preference, purchase, purchase intention, or pestering).

Double screening of papers on title and abstract and full-text were independently completed by K.M., G.S., J.W., and J.P. Discrepancies between reviewers were mutually reconciled. Full-texts of relevant articles were acquired via library and web services, in addition to direct contact with authors. All papers eligible for screening were retrieved successfully.

\subsection{Data Extraction and Items}

Data were independently extracted and jointly reconciled by K.M., G.S., and J.P. Corresponding authors were contacted to request additional data, where required, for the meta-analysis. Four corresponding authors were contacted, of whom one responded with the required data.

Data extracted included study identification (authors, country, year of publication), target population (children and/or adolescents), sample group description (size of sample, age range, and mean age of participants), study description (study design, number of participants in each condition and assignment to conditions), intervention description (advertising medium, celebrity/influencer), comparison type (HFSS food advertisement vs. healthy food or non-food advertisement), test foods used, outcome type (consumption, preference, or purchasing), and outcome measures (kcals, kJ, grams, preference ratings, purchase request measures).

\subsection{Assessment of Quality}

The Cochrane risk of bias tool RoB 2 was used to assess bias in the included experimental studies [50]. Bias assessment was conducted independently by two reviewers with discrepancies reconciled.

\subsection{Data Synthesis}

Our primary analysis was meta-analysis, but where studies did not provide sufficient data, they were included in a narrative synthesis. For inclusion in the meta-analysis, experimental studies were required to have an appropriate comparison group, including no advertisement or non-food advertisement. We considered these comparison groups due to the ubiquity of using celebrities in marketing of both food and non-food products and to be consistent with previous research [20]. Due to a lack of studies measuring preference or purchase of a HFSS product, meta-analysis was only possible for consumption outcomes. Three articles were identified that measured HFSS consumption and reported/provided the mean values with standard deviations. The consumption outcomes were standardized to report the total energy content consumed (kcals), which required conversion from weight (grams) using published nutritional values of the consumed products. Further details about the standardization methods, and the rationale for the experimental conditions and outcomes, were included in the meta-analysis, is provided in a supplemental file (Supplementary Table S3). Due to heterogeneity in study design, including the type of celebrity (sport or influencer), the advertising exposure (online static image, TV, or YouTube clip), and the HFSS products advertised and consumed (crisps or chocolate biscuit), a DerSimonian-Laird random-effects model was used for meta-analysis. We presented the results graphically using forest plots. Analyses were conducted using Stata 16 (16.1, StataCorp LLC, College Station, TX, USA) [51].

\section{Results}

\subsection{Study Selection}

The search process is shown in the flowchart (Figure 1). The searches resulted in 414 articles, of which 294 were unique records following the removal of duplicates. After screening on title and abstract, 264 were excluded and 30 were screened on full-text. One 
article was found through screening of a related review. This led to the inclusion of seven studies, from seven reports. Three studies were included in the meta-analysis.

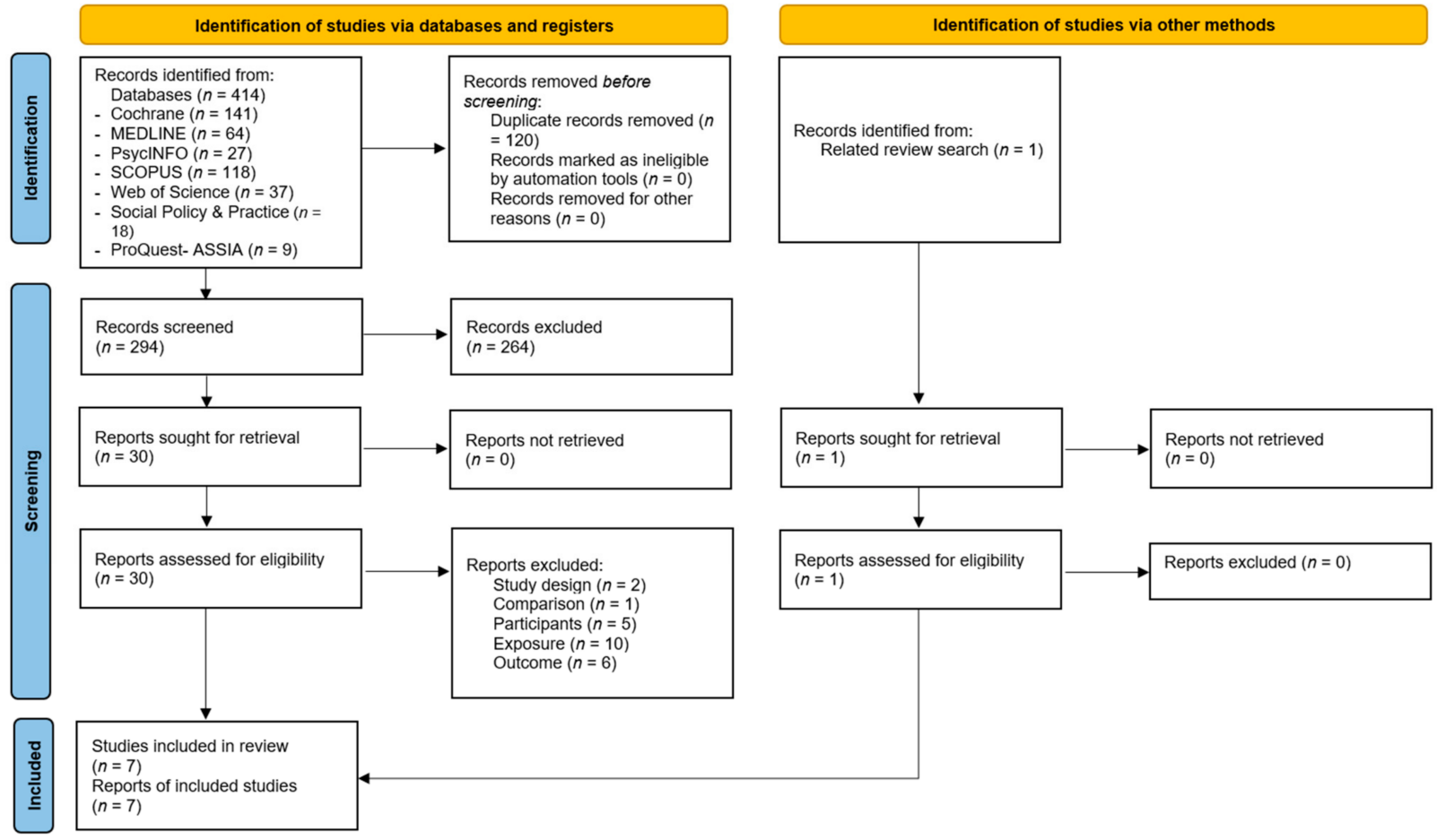

Figure 1. PRISMA screening flowchart.

\subsection{Study Description and Results}

A summary of study information is provided in Table 1.

Table 1. Descriptive table of experimental studies.

\begin{tabular}{|c|c|c|c|c|c|c|c|}
\hline $\begin{array}{l}\text { Author, Year, } \\
\text { Country }\end{array}$ & Participants & Design & $\begin{array}{l}\text { Advertising } \\
\text { Intervention }\end{array}$ & Comparison & Outcome & Relevant Results & $\begin{array}{c}\text { Risk of } \\
\text { Bias }\end{array}$ \\
\hline $\begin{array}{l}\text { Boyland [20], } \\
\text { 2013, } \\
\text { UK }\end{array}$ & $\begin{array}{c}\quad N=181 \\
\text { Age range }=8-11 \\
\text { Mean age }=10.3\end{array}$ & $\begin{array}{l}\text { Experimental } \\
\text { (school), } \\
\text { between-subject, } \\
\text { allocation not } \\
\text { specified }\end{array}$ & $\begin{array}{l}20 \text { min cartoon with } 45 \\
\text { s TV advert for HFSS } \\
\text { product (Walker's } \\
\text { crisps) with sports } \\
\text { celebrity endorser } \\
\text { (Gary Lineker) }\end{array}$ & $\begin{array}{l}20 \text { min cartoon } \\
\text { with } 45 \text { s non-food } \\
\text { advert; food } \\
\text { advert with no } \\
\text { endorser; or TV } \\
\text { footage of } \\
\text { endorser }\end{array}$ & $\begin{array}{l}\text { Post-intervention, ad } \\
\text { libitum } \\
\text { consumption of } \\
\text { potato } \\
\text { crisps, labeled } \\
\text { branded, and } \\
\text { non-branded } \\
\text { (grams) } \\
\end{array}$ & $\begin{array}{l}\text { Celebrity endorsed TV } \\
\text { food adverts } \\
\text { significantly increased } \\
\text { intake of food, } \\
\text { compared to food } \\
\text { advert with no } \\
\text { endorser and non-food } \\
\text { advert. }\end{array}$ & $\begin{array}{l}\text { Some } \\
\text { concerns }\end{array}$ \\
\hline $\begin{array}{c}\text { Coates [52], } \\
2019, \\
\text { UK } \\
\text { EoI }\end{array}$ & $\begin{array}{l}\quad N=151 \\
\text { Age range = 9-11 } \\
\text { Mean age }=10\end{array}$ & $\begin{array}{l}\text { Experimental } \\
\text { (school), } \\
\text { between-subject, } \\
\text { random } \\
\text { assignment }\end{array}$ & $\begin{array}{c}5 \text { min YouTube video } \\
\text { with } 1 \text { min influencer } \\
\text { marketing (Zoella and } \\
\text { PointlessBlog) segment } \\
\text { of branded HFSS } \\
\text { product (McVitie's } \\
\text { chocolate biscuits), } \\
\text { with and without } \\
\text { disclosure }\end{array}$ & $\begin{array}{l}5 \text { min YouTube } \\
\text { video with } 1 \mathrm{~min} \\
\text { influencer } \\
\text { marketing } \\
\text { segment of } \\
\text { branded non-food } \\
\text { product (Apple } \\
\text { iPhone) }\end{array}$ & $\begin{array}{c}\text { Post-intervention, ad } \\
\text { libitum consumption } \\
\text { of cookies (kcal), } \\
\text { labeled, branded, } \\
\text { and non-branded, } 5 \\
\text { min }\end{array}$ & $\begin{array}{l}\text { Influencer endorsed } \\
\text { HFSS advert } \\
\text { significantly increased } \\
\text { intake of promoted } \\
\text { food, compared to } \\
\text { non-food advert }\end{array}$ & Low \\
\hline $\begin{array}{l}\text { Coates [53], } \\
\text { 2019, } \\
\text { UK } \\
\text { SMI }\end{array}$ & $\begin{array}{c}\quad N=176 \\
\text { Age range }=9-11 \\
\text { Mean age }=10.5\end{array}$ & $\begin{array}{l}\text { Experimental } \\
\text { (school), } \\
\text { between-subject, } \\
\text { random } \\
\text { assignment }\end{array}$ & $\begin{array}{l}1 \text { min viewing of mock } \\
\text { Instagram profile of } \\
\text { popular YouTube } \\
\text { influencers (not stated } \\
\text { due to copyright) with } \\
\text { marketing of HFSS } \\
\text { product (unbranded } \\
\text { chocolate biscuits) }\end{array}$ & $\begin{array}{l}1 \text { min viewing of } \\
\text { mock Instagram } \\
\text { with image of } \\
\text { YouTube } \\
\text { influencer } \\
\text { marketing healthy } \\
\text { product (banana) } \\
\text { or non-food } \\
\text { (sneakers) }\end{array}$ & $\begin{array}{c}\text { Post-intervention, ad } \\
\text { libitum consumption } \\
\text { of unbranded HFSS } \\
\text { products HFSS } \\
\text { (candy, chocolate) } \\
\text { and healthy (carrot, } \\
\text { grapes) products } \\
\text { (kcal), } 10 \text { min }\end{array}$ & $\begin{array}{l}\text { Intake of HFSS } \\
\text { products and overall } \\
\text { snacks significantly } \\
\text { increased following } \\
\text { exposure to celebrity } \\
\text { endorsement of HFSS } \\
\text { products, compared to } \\
\text { non-food condition. }\end{array}$ & Low \\
\hline
\end{tabular}


Table 1. Cont.

\begin{tabular}{|c|c|c|c|c|c|c|c|}
\hline $\begin{array}{c}\text { De Jans [54], } \\
\text { 2021, } \\
\text { Belgium }\end{array}$ & $\begin{array}{l}\quad N=190 \\
\text { Age range }=8-12 \\
\text { Mean age }=10.04\end{array}$ & $\begin{array}{l}\text { Experimental } \\
\text { (classroom), } \\
\text { between-subject, } \\
\text { random }\end{array}$ & $\begin{array}{l}\text { Instagram post of } \\
\text { influencer (fictitious) } \\
\text { promotion of HFSS } \\
\text { snack (unbranded } \\
\text { donuts) (either } \\
\text { sedentary lifestyle } \\
\text { versus athletic lifestyle) }\end{array}$ & $\begin{array}{c}\text { Instagram post of } \\
\text { influencer } \\
\text { promotion of } \\
\text { snack high in } \\
\text { nutritional value } \\
\text { (strawberries) } \\
\text { (both (influencer } \\
\text { lifestyle: } \\
\text { sedentary versus } \\
\text { athletic) }\end{array}$ & $\begin{array}{l}\text { Snack choice } \\
\text { between mini donut } \\
\text { or a strawberry. }\end{array}$ & $\begin{array}{l}\text { Children exposed to } \\
\text { influencer promotion } \\
\text { of the donut, chose the } \\
\text { donut } 52.2 \%(47 / 90) \\
\text { compared to } 49.5 \% \\
\text { exposed to influencer } \\
\text { promotion of } \\
\text { non-HFSS product. } \\
\text { Significance not tested. }\end{array}$ & Low \\
\hline $\begin{array}{l}\text { Dixon [55], } \\
\text { 2014, } \\
\text { Australia }\end{array}$ & $\begin{array}{c}N=1302 \\
\text { Age range }=10-12 \\
\text { Mean age }=11\end{array}$ & $\begin{array}{c}\text { Experimental } \\
\text { (online school), } \\
\text { between-subject, } \\
\text { random } \\
\text { assignment }\end{array}$ & $\begin{array}{l}\text { Packaging of HFSS } \\
\text { products (cereal, cheese } \\
\text { dips, chicken nuggets, } \\
\text { ice cream, flavored } \\
\text { milk, brands not stated) } \\
\text { with sports celebrity } \\
\text { endorsement (popular } \\
\text { Australian male } \\
\text { athletes, names not } \\
\text { stated) }\end{array}$ & $\begin{array}{l}\text { Packaging of same } \\
\text { HFSS products } \\
\text { with no celebrity } \\
\text { endorsement (no } \\
\text { promotion) }\end{array}$ & $\begin{array}{l}\text { During-intervention, } \\
\text { forced choice of } \\
\text { randomly allocated } \\
\text { HFSS exposure or } \\
\text { comparable healthier } \\
\text { food pack, on a } \\
\text { computer }\end{array}$ & $\begin{array}{l}\text { Celebrity endorsed } \\
\text { HFSS products were } \\
\text { significantly more } \\
\text { likely to be chosen } \\
\text { compared to control, in } \\
\text { boys only. No } \\
\text { significant difference in } \\
\text { girls. }\end{array}$ & Low \\
\hline $\begin{array}{c}\text { Jain [56], } \\
\text { 2011, } \\
\text { India }\end{array}$ & $\begin{array}{l}\quad N=378 \\
\text { Age range }=13-17 \\
\text { Mean age }=\text { not } \\
\text { stated }\end{array}$ & $\begin{array}{l}\text { Experimental } \\
\text { (school), } \\
\text { between-subject, } \\
\text { allocation not } \\
\text { specified }\end{array}$ & $\begin{array}{l}5-10 \text { min viewing of } \\
\text { print advertisement of } \\
\text { HFSS product } \\
\text { (unbranded chocolate) } \\
\text { with celebrity } \\
\text { endorsement (Hindi } \\
\text { actor, Aamir Khan) }\end{array}$ & $\begin{array}{c}5-10 \text { min viewing } \\
\text { of print adverts of } \\
\text { HFSS product } \\
\text { with no } \\
\text { endorsement }\end{array}$ & $\begin{array}{l}\text { Post-intervention, } \\
\text { purchase intention } \\
\text { product (scale NS) }\end{array}$ & $\begin{array}{l}\text { Purchase intentions of } \\
\text { HFSS product } \\
\text { endorsed by a celebrity } \\
\text { were significantly } \\
\text { greater compared to } \\
\text { control or } \\
\text { character-endorsed } \\
\text { HFSS product. }\end{array}$ & $\begin{array}{l}\text { Some } \\
\text { concerns }\end{array}$ \\
\hline $\begin{array}{l}\text { Ponce- } \\
\text { Blandon [57], } \\
2020, \\
\text { Spain }\end{array}$ & $\begin{array}{c}N=421 \\
\text { Age range }=4-6 \\
\text { Mean age }=4.8\end{array}$ & $\begin{array}{l}\text { Experimental } \\
\text { (education } \\
\text { centers), } \\
\text { between-subject, } \\
\text { random } \\
\text { assignment }\end{array}$ & $\begin{array}{l}8 \text { min episode of } \\
\text { cartoon (Caillou) with } \\
\text { an advert for HFSS } \\
\text { product (Príncipe } \\
\text { Double Choc chocolate } \\
\text { cookies) with sports } \\
\text { celebrity (famous } \\
\text { Spanish soccer player, } \\
\text { name not stated) }\end{array}$ & $\begin{array}{l}\text { No advert control } \\
\text { and non-food } \\
\text { advert control }\end{array}$ & $\begin{array}{c}\text { Preference choice } \\
\text { between advertised } \\
\text { product (Príncipe } \\
\text { Double Choc } \\
\text { chocolate cookies) vs. } \\
\text { similar non } \\
\text { advertised product } \\
\text { (Tosta Rica } \\
\text { Chocoguay, Cuétara } \\
\text { chocolate cream } \\
\text { filled cookies) }\end{array}$ & $\begin{array}{l}\text { Preference for the } \\
\text { advertised product was } \\
\text { not significantly } \\
\text { different between the } \\
\text { conditions. }\end{array}$ & Low \\
\hline
\end{tabular}

\subsection{Participants}

The age of participants across all studies ranged from 6-17 years. One study included participants aged 13-17, and results were not split by age [56]. The range for the three studies in the meta-analysis was 8 to 11 years, and the mean age was 10.3 years.

\subsection{Settings}

All studies were experimental using between-subjects designs. All but two [20,56] stated that subjects were randomly allocated. All of the studies were conducted in schools or education centers. Studies were conducted in the UK ( $n=3$, same research group), India $(n=1)$, Belgium $(n=1)$, Australia $(n=1)$, and Spain $(n=1)$.

\subsection{Interventions}

The HFSS marketing exposure varied: TV advertisements, embedded in cartoons $(n=2)$ [20,57], an online advertisement embedded in a YouTube clip $(n=1)$ [52]; static Instagram posts $(n=2)[53,54]$; food product packaging $(n=1)$ [55]; and printed advertisements $(n=1)$ [56]. The celebrities featured influencers $(n=3)$, sports celebrities $(n=3)$, and a Hindi movie star $(n=1)$. The HFSS products included crisps, chocolate, chocolate biscuits, donuts, and sweetened cereals.

\subsection{Outcomes}

The outcome measures were ad libitum consumption of snacks immediately following the advertising exposure (from which total calories consumed could be calculated) and self-reported consumption intention $(n=3)[20,52,53]$, preference/snack choice between paired items $(n=3)[54,55,57]$, and self-reported purchase intention $(n=1)$ [56]. The HFSS products available for ad libitum consumption were crisps, chocolate biscuits, and jelly candy/chocolate buttons. Duration of snacking, when reported, was between 5-10 min. 


\subsection{Comparisons}

Calorie consumption following viewing of advertisements of HFSS products with celebrities was compared to consumption following non-food advertisements with or without celebrity endorsements in the three studies included in the meta-analysis [20,52,53]. Of the studies not included in the meta-analysis, two studies compared marketing of a HFSS product with celebrity endorsement to the same HFSS product without celebrity endorsement packaging [55] or print advertisement [56]; one study compared TV advertisements with celebrity endorsement for HFSS product to non-exposure or non-food TV advertisements [57]; and one study compared Instagram posts with influencers for HFSS products to Instagram posts with influencers for non-HFSS food products [54].

\subsection{Meta-Analysis}

Three studies provided sufficient data on calorie consumption to be included in meta-analysis of consumption. We found that use of a celebrity in HFSS food marketing, compared to non-food marketing, resulted in significantly greater consumption of HFSS products, with a pooled effect size of $56.4 \mathrm{kcals}(95 \%$ CI 8.50, 104.20; $p=0.021)$ (Figure 2). We found evidence of high heterogeneity $\left(\mathrm{I}^{2}=79.5 \%\right)$; Egger's regression analysis showed low risk of publication bias $(p=0.347)$; and trim and fill analysis suggested evidence of two missing studies (See Supplementary Figure S1).

Study ID

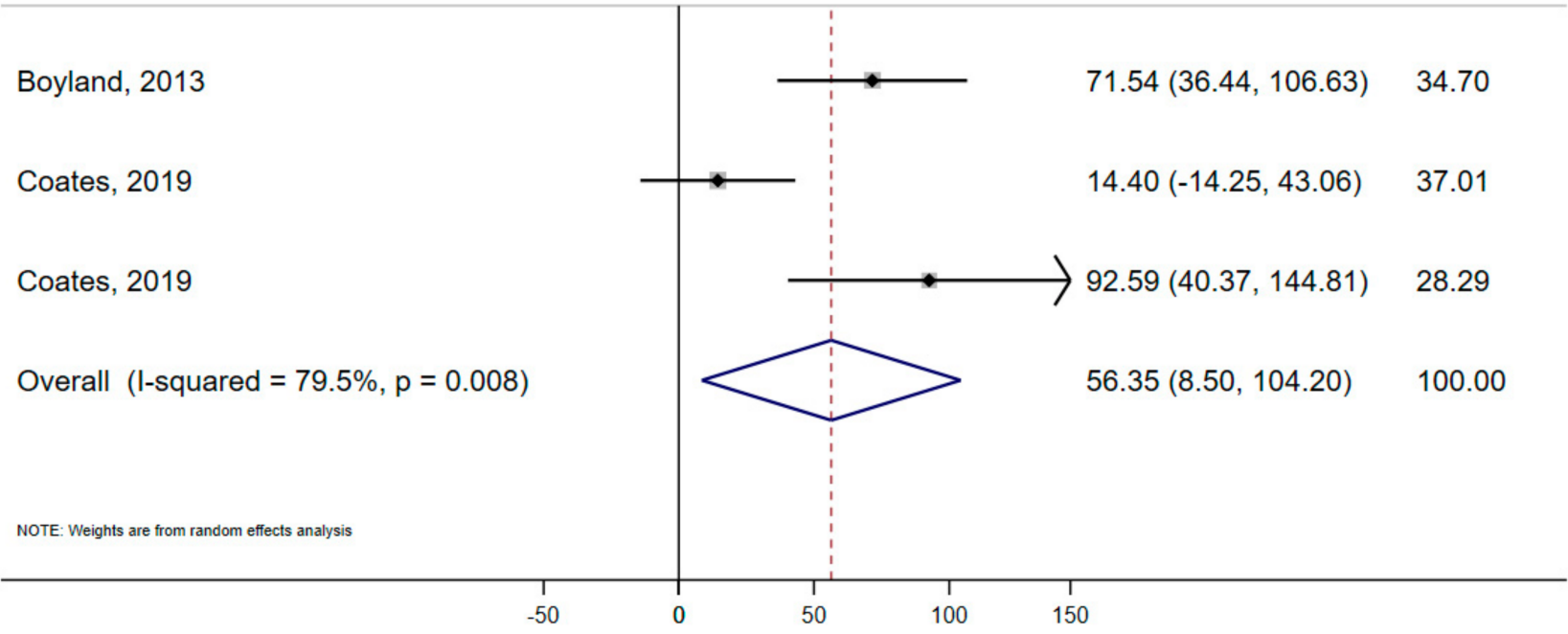

Figure 2. Forest plot showing mean difference (kcals) in total snack consumption of HFSS products between celebrity HFSS advertisement and non-food advertisement. Boyland, 2013; Coates, 2019; Coates, 2019.

\subsection{Other Findings}

One study measured purchase intentions and found purchase intentions for HFSS products were significantly greater in the celebrity HFSS advertisement group compared to non-food advertisement [56]. Preference was measured in three studies, with mixed results [55]. One found that when exposed to product packaging featuring an endorsement from a sports celebrity that product was chosen by participants significantly more when compared to the same product with no endorsement; however, this effect was only seen in boys [55]. Two studies found that preference for HFSS product was not significantly different with celebrity-endorsed HFSS product advertisement exposure compared to no advertisement exposure or non-food advertisement control [57] or non-HFSS food product [54]. The impact of SES was only reported in one study, which found no association 
between SES and food preference in response to HFSS advertising [55]. Impact of age was measured in three studies and was found to not be significantly associated with consumption $(n=2)[20,52]$ or consumption preference [57]. We were unable to assess the secondary aims of differential impact of celebrity type or format of advertisement, as the data did not support this. None of the included studies were longitudinal; therefore, long-term consequences of these effects could also not be assessed. Across all studies, there was little evidence relating to comparisons between use and non-use of celebrities and influencers (i.e., endorsed vs. non-endorsed) in HFSS food marketing.

\subsection{Quality of Studies}

The risk of bias across included studies was assessed as mostly low (see Supplementary Figure S2 for bias assessment).

\section{Discussion}

Our systematic review included the first meta-analysis examining the impact of celebrities used in the marketing of HFSS products to children and found evidence that marketing HFSS products with celebrities' influences children's calorie consumption. The meta-analysis showed that HFSS advertisements with a celebrity endorser, compared to a non-food advertisement, resulted in significantly greater calorie intake in children under experimental conditions. We found limited evidence that celebrities impact purchase intentions and mixed evidence that they impact preference outcomes. The findings from our review extend the findings of previous reviews, which have indicated that celebrities are persuasive HFSS marketing tools [11,45-47]. Our previous work showed that, following exposure to screen advertising for food, children consumed an additional $57 \mathrm{kcals}$ [7] when compared to non-food advertisement exposure, which is consistent with the finding here of an additional $56.4 \mathrm{kcals}$. The impacts of advertising may be modest but over time can accrue to have substantial impacts on energy balance, body weight, and associated morbidities [58,59].

There was limited evidence that age did not impact on consumption outcomes but only one study examined the impact of SES and found no evidence. A review recently found that children from ethnic minority and low SES backgrounds are exposed to more HFSS advertising than children from higher SES and non-ethnic minority backgrounds [6]. This emphasizes the need for policy actions that addresses these inequalities.

Our data suggest there is potential for population-level interventions, including policy action such as enhanced regulations, to have an impact on HFSS consumption by children, even if effects are modest at an individual level. The use of celebrities in HFSS marketing is often not restricted or subject to weak regulations, and greater policy action has been recommended by WHO. The quantifiable impact of celebrities on children's dietary outcomes has not been previously evidenced in the literature $[18,19]$. Our findings suggest that tightening policies regulating HFSS marketing directed at children that contain celebrities may be effective in reducing children's calorie intake. Celebrity-endorsed HFSS brand advertising is frequently omitted from regulations, due to complexities in identifying advertised products and assessing if restrictions are applicable [60]. An additional concern with using celebrities in HFSS marketing is the knock-on effect of exposure to them in contexts outside of HFSS advertisements. This has been shown to increase consumption of the HFSS food (seeing Gary Lineker in Match of the Day led to children eating more Walkers crisps) [20]. Chile has implemented policies that comprehensively restrict use of celebrities, and these have been shown to be effective at reducing HFSS food marketing to children $[19,60,61]$. The UK government announced plans to introduce a pre-watershed ban on HFSS advertisements across television and on-demand program services, and a restriction on paid-for less healthy food and drink advertising online, which could be effective at overcoming some gaps and limiting exposure of celebrities in HFSS marketing to children [60,61]. These policies touch on areas where regulations could be strengthened including a standardization of approaches to achieve a consistent definition of celebrities, scope (programs and medias), 
audience thresholds (approved composition of the audience i.e., proportion of children), and enforcement. In the UK, only celebrities 'popular with children' are restricted (but this is not defined), allowing free use of celebrities with general appeal, such as Gary Lineker, and unrestricted endorsement opportunities for influencers [18,19]. Certain regulations (e.g., Ireland, UK, and the EU pledge) only apply if children make up between $20-50 \%$ of the viewing audience, but quantifying the audience demographics for broadcast and non-broadcast media is difficult to accurately assess [18]. This is especially true online, where user age restrictions on social media platforms are rarely followed by site users and children often use their parents' account or devices [3]. Restrictions specific to children's programs, mean that family programs popular with children and broadcast during peak children viewing times (6-9 p.m. in the UK) are out of scope in many jurisdictions but could be overcome by total bans on HFSS advertising, such as the proposed pre-watershed ban in the UK $[3,29]$.

Limitations of this review include the small number of search results and limited number of studies eligible for inclusion in meta-analysis; therefore, care needs to be taken due to variability. The heterogeneity of the included studies was high, but the random effects model was used to account for differences. Findings from the meta-analysis should be interpreted with caution, as all studies were completed by the same research team at the University of Liverpool but conducted to a high standard. Further primary research would be beneficial in building the evidence base, especially digital marketing. We were unable to address the secondary aims, due to a lack of data. Despite our search including real-world studies, we were unable to identify any and therefore were unable to investigate the long-term impacts of celebrity endorsers on dietary outcomes. Beyond age, we were unable to assess the influence of SES on impact of advertising and in future would also examine the impact of weight status and ethnicity. We were unable to assess if there were any changes due to COVID-19, as no papers specifically mention this and most of the data was collected pre-2020. Due to the data available, we were unable to complete metaanalysis comparing use and non-use of celebrities and influencers in HFSS marketing and the impact on dietary outcomes (i.e., endorsed vs. non-endorsed). We suggest this as an area for future primary research; it is also a limitation about the difficulty of separating the effect of celebrity from marketing more generally. The impact of celebrity and influencers on promoting healthier food products was not the focus of this review and could be another area of future research. Evidence suggests food adverts do not appear to work in the same way for healthy food [62].

\section{Conclusions}

We found evidence that HFSS food marketing featuring celebrities or influencers increases children's food consumption, although this was from a limited number of studies. These findings suggest that limiting exposure of children to HFSS marketing including all celebrity types may have beneficial impacts upon dietary consumption. Further research on the impact of child characteristics such as SES, long-term impacts, and real-world studies would be beneficial to further inform the thinking of policy makers.

Supplementary Materials: The following supporting information can be downloaded at: https: / /www.mdpi.com/article/10.3390/nu14030434/s1, Table S1: Details of search, Table S2: Search history, Table S3: Rationale for meta-analysis inclusion and data processing, Figure S1: Trim and fill analysis, Figure S2: Bias assessment for experimental studies

Author Contributions: Conceptualization, J.P., H.C., R.M.V., S.J.R. and C.S.; methodology, J.P., H.C., C.S., G.S. and K.M.; software, J.P., H.C., C.S., G.S. and K.M.; validation, J.P., H.C., G.S. and K.M.; formal analysis, J.P. and H.C.; investigation, J.P., H.C., G.S. and K.M.; resources, J.P., H.C., G.S. and K.M.; data curation, J.P., H.C., G.S. and K.M.; writing-original draft preparation, J.P. and H.C.; writing - review and editing, J.P., H.C., C.S., S.J.R., R.M.V., G.S. and K.M.; visualization, J.P.; supervision, H.C. and R.M.V.; project administration, H.C. and R.M.V.; funding acquisition, R.M.V. All authors have read and agreed to the published version of the manuscript. 
Funding: This report is independent research commissioned and funded by the National Institute for Health Research Policy Research Program. The views expressed in this publication are those of the authors and not necessarily those of the NHS, the National Institute for Health Research, the Department of Health and Social Care or its arm's length bodies, and other Government Departments.

Institutional Review Board Statement: Not applicable.

Informed Consent Statement: Not applicable.

Data Availability Statement: The data presented in this study are available in Boyland [20], 2013; Coates [52], 2019; Coates [53], 2019.

Acknowledgments: We thank Semina Michalopoulou and Jamie Wong for their assistance in bias assessment and screening, respectively.

Conflicts of Interest: The authors declare no conflict of interest.

\section{References}

1. Sahoo, K.; Sahoo, B.; Choudhury, A.K.; Sofi, N.Y.; Kumar, R.; Bhadoria, A.S. Childhood obesity: Causes and consequences. J. Fam. Med. Prim. Care 2015, 4, 187-192. [CrossRef]

2. Lapierre, M.A.; Fleming-Milici, F.; Rozendaal, E.; McAlister, A.R.; Castonguay, J. The Effect of Advertising on Children and Adolescents. Pediatrics 2017, 140, S152. [CrossRef]

3. Ofcom. Children and Parents: Media Use and Attitudes Report 2018. 2019. Available online: https://www.ofcom.org.uk/__ data/assets/pdf_file/0024/134907/children-and-parents-media-use-and-attitudes-2018.pdf (accessed on 9 December 2021).

4. Griffith, R.; O'Connell, M.; Smith, K.; Stroud, R. Children's Exposure to TV Advertising of Food and Drink; The Institute for Fiscal Studies: London, UK, 2018; Available online: https:/ /www.ifs.org.uk/uploads/publications/bns/BN238.pdf (accessed on 9 December 2021).

5. Boyland, E.J.; Whalen, R. Food advertising to children and its effects on diet: Review of recent prevalence and impact data Pediatric Diabetes 2015, 16, 331-337. [CrossRef]

6. Backholer, K.; Gupta, A.; Zorbas, C.; Bennett, R.; Huse, O.; Chung, A.; Isaacs, A.; Golds, G.; Kelly, B.; Peeters, A. Differential exposure to, and potential impact of, unhealthy advertising to children by socio-economic and ethnic groups: A systematic review of the evidence. Obes. Rev. 2020, 22, e13144. [CrossRef] [PubMed]

7. Russell, S.J.; Croker, H.; Viner, R.M. The effect of screen advertising on children's dietary intake: A systematic review and meta-analysis. Obes. Rev. 2019, 20, 554-568. [CrossRef]

8. Clark, H.; Coll-Seck, A.M.; Banerjee, A.; Peterson, S.; Dalglish, S.L.; Ameratunga, S.; Balabanova, D.; Bhan, M.K.; Bhutta, Z.A.; Borrazzo, J.; et al. A future for the world's children? A WHO-UNICEF-Lancet Commission. Lancet 2020, 395, 605-658. [CrossRef]

9. WHO. Set of Recommendations on the Marketing of Foods and Non-Alcoholic Beverages to Children; World Health Organization: Geneva, Switzerland, 2010; Available online: https://apps.who.int/iris/bitstream/handle/10665/44416/9789241500210_eng.pdf (accessed on 9 December 2021).

10. WHO. A Framework for Implementing the Set of Recommendations on the Marketing of Foods and Non-Alcoholic Beverages to Children; World Health Organization: Geneva, Switzerland, 2012; Available online: https:/ /www.who.int/dietphysicalactivity/ MarketingFramework2012.pdf (accessed on 9 December 2021).

11. Bergkvist, L.; Zhou, K.Q. Celebrity endorsements: A literature review and research agenda. Int. J. Advert. 2016, 35, 642-663. [CrossRef]

12. Cuomo, M.T.; Foroudi, P.; Tortora, D.; Hussain, S.; Melewar, T.C. Celebrity Endorsement and the Attitude Towards Luxury Brands for Sustainable Consumption. Sustainability 2019, 11, 6791. [CrossRef]

13. Elberse, A.; Verleun, J. The Economic Value of Celebrity Endorsements. J. Advert. Res. 2012, 52, 149. [CrossRef]

14. Knoll, J.; Matthes, J. The effectiveness of celebrity endorsements: A meta-analysis. J. Acad. Mark. Sci. 2017, 45, 55-75. [CrossRef]

15. De Houwer, J.; Thomas, S.; Baeyens, F. Associative learning of likes and dislikes: A review of 25 years of research on human evaluative conditioning. Psychol. Bull. 2001, 127, 853-869. [CrossRef] [PubMed]

16. Aw, E.C.-X.; Labrecque, L.I. Celebrity endorsement in social media contexts: Understanding the role of parasocial interactions and the need to belong. J. Consum. Mark. 2020, 37, 895-908. [CrossRef]

17. Hoffman, S.J.; Tan, C. Biological, psychological and social processes that explain celebrities' influence on patients' health-related behaviors. Arch. Public Health 2015, 73, 3. [CrossRef]

18. WHO. Evaluating Implementation of the WHO Set of Recommendations on the Marketing of Foods and Non-Alcoholic Beverages to Children World Health Organization: Geneva, Switzerland, 2018; Available online: https://www.euro.who.int/_data/assets/pdf_file/00 03/384015/food-marketing-kids-eng.pdf (accessed on 9 December 2021).

19. Taillie, L.S.; Busey, E.; Stoltze, F.M.; Dillman Carpentier, F.R. Governmental policies to reduce unhealthy food marketing to children. Nutr. Rev. 2019, 77, 787-816. [CrossRef] [PubMed]

20. Boyland, E.J.; Harrold, J.A.; Dovey, T.M.; Allison, M.; Dobson, S.; Jacobs, M.C.; Halford, J.C. Food choice and overconsumption: Effect of a premium sports celebrity endorser. J. Pediatr. 2013, 163, 339-343. [CrossRef] [PubMed] 
21. WCRF. Restrict Food Advertising and Other Forms of Commercial Promotion; WCRF: London, UK, 2019; Available online: https: / / policydatabase.wcrf.org/level_one?page=nourishing-level-one\#step2=3 (accessed on 9 December 2021).

22. Hawkes, C. Marketing Food to Children: Changes in the Global Regulatory Environment 2004-2006; World Health Organization: Geneva Switzerland, 2007; Available online: https://www.who.int/dietphysicalactivity/regulatory_environment_CHawkes07.pdf (accessed on 9 December 2021).

23. Australian Communications and Media Authority. Guide to the Children's Television Standards 2009. Available online: https: //www.acma.gov.au/sites/default/files/2019-06/Previous-guide-to-the-Childrens-Television-Standards-2009.pdf (accessed on 9 December 2021).

24. WHO. Marketing of Foods High in Fat, Salt and Sugar to Children: Update 2012-2013; WHO Regional Office: Copenhagen, Denmark, 2013; Available online: http:/ / www.euro.who.int/_data/assets/pdf_file/0019/191125/e96859.pdf (accessed on 9 December 2021).

25. Advertising Standards Authority. The BCAP Code-The UK Code of Broadcast Advertising; The Advertising Standards Authority: London, UK, 2018; Available online: https://www.asa.org.uk/static/846f25eb-f474-47c1-ab3ff571e3db5910/BCAP-Code-full.pdf (accessed on 9 December 2021).

26. Advertising Standards Authority. The CAP Code-The UK Code of Non-Broadcast Advertising and Direct E Promotional Marketing; The Advertising Standards Authority: London, UK, 2018; Available online: https://www.asa.org.uk/static/47eb51e7-028d-4509 -ab3c0f4822c9a3c4/bbca4ed3-9b41-4c6b-8d13299664f119be/The-Cap-code.pdf (accessed on 9 December 2021).

27. Boyland, E.J.; Harris, J.L. Regulation of food marketing to children: Are statutory or industry self-governed systems effective? Public Health Nutr. 2017, 20, 761-764. [CrossRef] [PubMed]

28. Zhou, M.; Rincón-Gallardo Patiño, S.; Hedrick, V.E.; Kraak, V.I. An accountability evaluation for the responsible use of celebrity endorsement by the food and beverage industry to promote healthy food environments for young Americans: A narrative review to inform obesity prevention policy. Obes. Rev. 2020, 21, e13094. [CrossRef]

29. Department of Health and Social Care. Introducing Further Advertising Restrictions on TV and Online for Products High in Fat, Sugar and Salt (HFSS). Available online: https:/ / assets.publishing.service.gov.uk/government/uploads/system/uploads/ attachment_data/file/807378/hfss-advertising-consultation-10-april-2019.pdf (accessed on 9 December 2021).

30. León-Flández, K.; Rico-Gómez, A.; Moya-Geromin, M.; Romero-Fernández, M.; Bosqued-Estefania, M.J.; Damián, J.; LópezJurado, L.; Royo-Bordonada, M. Evaluation of compliance with the Spanish Code of self-regulation of food and drinks advertising directed at children under the age of 12 years in Spain, 2012. Public Health 2017, 150, 121-129. [CrossRef]

31. House of Lords. UK Advertising in a Digital Age; Authority of the House of Lords: London, UK, 2018; Available online: https:/ / publications.parliament.uk/pa/ld201719/ldselect/ldcomuni/116/116.pdf (accessed on 9 December 2021).

32. Schouten, A.P.; Janssen, L.; Verspaget, M. Celebrity vs. Influencer endorsements in advertising: The role of identification, credibility, and Product-Endorser fit. Int. J. Advert. 2020, 39, 258-281. [CrossRef]

33. De Veirman, M.; Hudders, L.; Nelson, M.R. What Is Influencer Marketing and How Does It Target Children? A Review and Direction for Future Research. Front. Psychol. 2019, 10, 2685. [CrossRef]

34. Russell, C.A.; Rasolofoarison, D. Uncovering the power of natural endorsements: A comparison with celebrity-endorsed advertising and product placements. Int. J. Advert. 2017, 36, 761-778. [CrossRef]

35. Phillipson, L.J.; Jones, S.C. I eat Milo to make me run faster: How the use of sport in food marketing may influence the food beliefs of young Australians. Proc. Aust. N. Z. Mark. Acad. Conf. 2008, 1-7. Available online: https://ro.uow.edu.au/cgi/viewcontent. cgi? article $=3332 \&$ context $=$ hbspapers (accessed on 9 December 2021).

36. Boyland, E.J.; Harrold, J.A.; Kirkham, T.C.; Halford, J.C. Persuasive techniques used in television advertisements to market foods to UK children. Appetite 2012, 58, 658-664. [CrossRef]

37. Bragg, M.A.; Miller, A.N.; Elizee, J.; Dighe, S.; Elbel, B.D. Popular Music Celebrity Endorsements in Food and Nonalcoholic Beverage Marketing. Pediatrics 2016, 138, e20153977. [CrossRef]

38. Bragg, M.A.; Yanamadala, S.; Roberto, C.A.; Harris, J.L.; Brownell, K.D. Athlete endorsements in food marketing. Pediatrics 2013, 132, 805-810. [CrossRef] [PubMed]

39. Alruwaily, A.; Mangold, C.; Greene, T.; Arshonsky, J.; Cassidy, O.; Pomeranz, J.L.; Bragg, M. Child Social Media Influencers and Unhealthy Food Product Placement. Pediatrics 2020, 146, e20194057. [CrossRef] [PubMed]

40. Hebden, L.; King, L.; Kelly, B.; Chapman, K.; Innes-Hughes, C. A menagerie of promotional characters: Promoting food to children through food packaging. J. Nutr. Educ. Behav. 2011, 43, 349-355. [CrossRef] [PubMed]

41. Potvin Kent, M.; Pauzé, E.; Roy, E.A.; de Billy, N.; Czoli, C. Children and adolescents' exposure to food and beverage marketing in social media apps. Pediatr. Obes. 2019, 14, e12508. [CrossRef] [PubMed]

42. Blades, M.; Oates, C.; Li, S. Children's recognition of advertisements on television and on Web pages. Appetite 2013, 62, 190-193. [CrossRef]

43. Rozendaal, E.; Buijzen, M.; Valkenburg, P. Comparing Children's and Adults' Cognitive Advertising Competences in the Netherlands. J. Child. Media 2010, 4, 77-89. [CrossRef]

44. Smit, C.R.; Buijs, L.; van Woudenberg, T.J.; Bevelander, K.E.; Buijzen, M. The Impact of Social Media Influencers on Children's Dietary Behaviors. Front. Psychol. 2020, 10, 2975. [CrossRef]

45. Jenkin, G.; Madhvani, N.; Signal, L.; Bowers, S. A systematic review of persuasive marketing techniques to promote food to children on television. Obes. Rev. 2014, 15, 281-293. [CrossRef] [PubMed] 
46. Cairns, G.; Angus, K.; Hastings, G.; Caraher, M. Systematic reviews of the evidence on the nature, extent and effects of food marketing to children. A retrospective summary. Appetite 2013, 62, 209-215. [CrossRef] [PubMed]

47. Smith, R.; Kelly, B.; Yeatman, H.; Boyland, E. Food Marketing Influences Children's Attitudes, Preferences and Consumption: A Systematic Critical Review. Nutrients 2019, 11, 875. [CrossRef]

48. Moher, D.; Liberati, A.; Tetzlaff, J.; Altman, D.G. Preferred reporting items for systematic reviews and meta-analyses: The PRISMA statement. BMJ 2009, 339, b2535. [CrossRef] [PubMed]

49. Thomas, J.; Brunton, J.; Graziosi, S. EPPI-Reviewer 4.0: Software for Research Synthesis; Social Science Research Unit, Institute of Education, University of London: London, UK, 2010.

50. Sterne, J.A.C.; Savović, J.; Page, M.J.; Elbers, R.G.; Blencowe, N.S.; Boutron, I.; Cates, C.J.; Cheng, H.-Y.; Corbett, M.S.; Eldridge, S.M.; et al. RoB 2: A revised tool for assessing risk of bias in randomised trials. BMJ 2019, 366, 14898. [CrossRef]

51. StataCorp. Stata Statistical Software: Release 16; StataCorp LLC.: College Station, TX, USA, 2019.

52. Coates, A.E.; Hardman, C.A.; Halford, J.C.G.; Christiansen, P.; Boyland, E.J. The effect of influencer marketing of food and a "protective" advertising disclosure on children's food intake. Pediatr. Obes. 2019, 14, e12540. [CrossRef] [PubMed]

53. Coates, A.E.; Hardman, C.A.; Halford, J.C.G.; Christiansen, P.; Boyland, E.J. Social Media Influencer Marketing and Children's Food Intake: A Randomized Trial. Pediatrics 2019, 143, e20182554. [CrossRef] [PubMed]

54. De Jans, S.; Spielvogel, I.; Naderer, B.; Hudders, L. Digital food marketing to children: How an influencer's lifestyle can stimulate healthy food choices among children. Appetite 2021, 162, 105182. [CrossRef]

55. Dixon, H.; Scully, M.; Niven, P.; Kelly, B.; Chapman, K.; Donovan, R.; Martin, J.; Baur, L.A.; Crawford, D.; Wakefield, M. Effects of nutrient content claims, sports celebrity endorsements and premium offers on pre-adolescent children's food preferences: Experimental research. Pediatr. Obes. 2014, 9, e47-e57. [CrossRef]

56. Jain, V.; Roy, S.; Daswani, A.; Sudha, M. What really works for teenagers: Human or fictional celebrity? Young Consum. 2011, 12, 171-183. [CrossRef]

57. Ponce-Blandón, J.A.; Pabón-Carrasco, M.; Romero-Castillo, R.; Romero-Martín, M.; Jiménez-Picón, N.; Lomas-Campos, M.d.L.M. Effects of Advertising on Food Consumption Preferences in Children. Nutrients 2020, 12, 3337. [CrossRef]

58. Public Health England. Calorie Reduction: The Scope and Ambition for Action; Public Health England: London, UK, 2018. Available online: https://assets.publishing.service.gov.uk/government/uploads/system/uploads/attachment_data/file/800675 /Calories_Evidence_Document.pdf (accessed on 9 December 2021).

59. Mytton, O.T.; Boyland, E.; Adams, J.; Collins, B.; O'Connell, M.; Russell, S.J.; Smith, K.; Stroud, R.; Viner, R.M.; Cobiac, L.J. The potential health impact of restricting less-healthy food and beverage advertising on UK television between 05.30 and 21.00 hours: A modelling study. PLoS Med. 2020, 17, e1003212. [CrossRef] [PubMed]

60. Department of Health and Social Care. New Advertising Rules to Help Tackle Childhood Obesity. 2021. Available online: https://www.gov.uk/government/news/new-advertising-rules-to-help-tackle-childhood-obesity (accessed on 9 December 2021).

61. Department of Health and Social Care. Introducing Further Advertising Restrictions on TV and Online for Products High in Fat, Salt and Sugar: Government Response-Consultation Outcome. Available online: https://www.gov.uk/ government/consultations/further-advertising-restrictions-for-products-high-in-fat-salt-and-sugar/outcome/introducingfurther-advertising-restrictions-on-tv-and-online-for-products-high-in-fat-salt-and-sugar-government-response (accessed on 9 December 2021).

62. Dovey, T.M.; Taylor, L.; Stow, R.; Boyland, E.J.; Halford, J.C. Responsiveness to healthy television (TV) food advertisements/commercials is only evident in children under the age of seven with low food neophobia. Appetite 2011, 56, 440-446. [CrossRef] [PubMed] 